\title{
Congenital Posteromedial Bowing of the Tibia: A Single Center Experience
}

\author{
Dragoljub Živanović ${ }^{1,2}$, Andjelka Slavkovići,2, Zoran Marjanović1,2, Ivona Djordjević1,2, \\ Nikola Bojović2 ${ }^{2}$ Milan Petrović ${ }^{1}$ \\ ${ }^{1}$ University of Niš, Faculty of Medicine, Niš, Serbia \\ ${ }^{2}$ Clinic of Pediatric Surgery and Orthopedics, Clinical Centre Niš, Niš, Serbia
}

SUMMARY

Congenital posteromedial bowing of the tibia (CPMBT) is a rare congenital anomaly of the lower limbs. The aim of the present study was to analyze our experience in the treatment of CPMBT.

A retrospective study of patients treated for CPMBT in the period January 2000 - June 2016 was performed. In the observed period, six patients were treated (five girls and one boy), with predominance of the right tibia involvement (5:1).

The initial treatment included a series of corrective casts (4-9) applied in all patients, followed by removable splints and physiotherapy. Four children with residual angulation of tibia after walking age were prescribed ankle-foot orthosis (AFO) as a prevention of pathological fractures. Both posterior and medial angulation correct over time. Mean initial shortening was $11 \mathrm{~mm}$. At the last follow-up visit, mean shortening was $23.33 \mathrm{~mm}$. Three patients had lower limb shortening of more than $2 \mathrm{~cm}$. In two of them, with shortening of $27 \mathrm{~mm}$ and $35 \mathrm{~mm}$, Ilizarov lengthening was performed. In one girl, we performed lengthening over titanium elastic nails. In the other girl, after lengthening, circular frame was exchanged with a locking plate to reduce fixator wearing time. There were no major complications of treatment. Patients were followed up for 2-12 years (mean 6.83 years). None of them reached skeletal maturity yet.

Primary manifestation of CPMBT - angulation of tibia and fibula as well as calcaneovalgus deformity usually correct spontaneously or with conservative measures. However, limb length inequality, as a consequence of CPMBT, progresses with growth and may require surgical correction in some children. Therefore, all children with CPMBT should be followed up until skeletal maturity.

Key words: posteromedial bow, congenital anomaly, limb lengthening, Ilizarov, deformity correction

Corresponding author:

Dragoljub Živanović

Email: dragoljub.zivanovic@medfak.ni.ac.rs 


\section{INTRODUCTION}

Congenital posteromedial bowing or angulation of the tibia (CPMBT) is a rare congenital anomaly of the lower limbs. Occasionally, it is diagnosed prenatally by ultrasound as early as at 20 weeks of gestation (1), but in most cases it is diagnosed at birth (2). Etiology and pathogenesis of the anomaly still remains unclear (3). Typical clinical presentation at birth is shortened and bowed leg, with angulation in two planes, directed posteriorly and medially. Foot is usually in severe to extreme calcaneovalgus. Bowing is in distal or medial third of the tibia shaft and it affects only one leg (4). Angle of angulation varies from 25 to 70 degrees. The degree of calcaneovalgus also varies in severity. In most severe cases dorsum of the foot lies on the anterolateral surface of the lower leg. In almost all cases foot cannot be brought to the neutral position. A range of motion of talocrural joint is limited and this limitation persist to some extent for the lifetime (5). Shortening of the leg is evident at birth and it increases with age. Earlier studies demonstrated that the extent of shortening was unrelated to the degree of angulation $(4,5)$. In more recent studies, the relation between the degree of shortening and the degree of medial bowing has been established. However, no relation between shortening and extent of posterior bowing could be demonstrated $(6,7)$. Initial treatment usually consists of a series of the above knee casts, followed by stretching exercises $(2,4$, 8). Correction is maintained by splints or orthosis. Angulation of the tibia that persists until walking age may be a predisposing factor for pathologic fracture. Thus, prophylactic ankle-foot orthosis (AFO) may be prescribed (9). Slow, but steady spontaneous correction of angulation may be expected in the first four years of life (2), although it is usually incomplete. Mild limb length discrepancies (LLD) could be compensated by simple shoe inserts to prevent limping. In more severe LLD, up to $2.5 \mathrm{~cm}$ contralateral epiphysiodesis may be performed. For a long time, this was the only suggested equalization procedure for CPMBT (4). Later on, limb lengthening procedures that used distraction osteogenesis emerged and gained popularity, regardless of utilized distraction devices $(2,5)$. Persisting angulations of tibia greater than 35 degrees should be surgically corrected with simultaneous limb lengthening procedure, via single or multilevel osteotomies (10). Finally, all patients with CPMBT should be followed until skeletal maturity (6). The aim of the present study was to analyze our single center experience in the treatment of CPMBT.

\section{MATERIALS AND METHODS}

We performed a retrospective study of patients' inpatient and outpatient charts for the period of January 2000 - June 2016 for term congenital posteromedial bowing of the tibia. Inclusion criteria were the diagnosis of CPMBT. Six patients met the study criteria. Three patients were referred from our tertiary center delivery unit and other three patients from delivery wards of regional, secondary level hospitals. Conservative treatment with a series of the above-knee casts started immediately in all six patients. Once full plantar flexion of the foot has been achieved, a removable above knee splint was applied and physiotherapy was instituted. The splint was applied with the foot in maximal correction and was removed for physical therapy and exercises performed by parents at home and bathing. On the initial visit, x-rays of both whole lower extremities in AP plane and lateral view of the affected leg was obtained. Limb length discrepancy was measured from radiographs and clinically. Clinically, limb length was measured from the superior anterior iliac spine (SIAS) to the medial malleolus (absolute length) and from the umbilicus to the medal malleolus (relative length). Clinically, LLD was assessed in sixmonth-intervals and radiographs were taken in yearly intervals. An AP view of both legs was obtained for the assessment of LLD and degree of correction of medial bowing, and lateral view of the affected leg was done for the assessment of posterior angulation of the tibia. In four patients with persistent residual angulation, AFO was prescribed after the walking age. If the patient had limp due to LLD, shoe insert was prescribed initially. If LLD exceeded $2 \mathrm{~cm}$, equalization procedures were discussed with parents. In two children, limb lengthening with Synthes@ circular titanium frame of llizarov type was performed. In the first patient, lengthening was performed over intramedullary titanium elastic nails (TEN). In the second patient, after coplition of distraction, a locking compression plate (LCP) was inserted and frame was dismounted to reduce fixator wearing time. In both patients proximal corticotomies of tibia were performed along with osteotomy of the fibula. Data from patients' records, operative records and notes from outpatient visits were extracted and entered in MS Excel(C spreadsheet for further analysis. For patients who underwent lengthening procedures, data on type of operation, device used, time of lengthening, period until frame removal, additional procedures and complications were collected. Data on patients' demographics, LLD, treatment and follow-up are summarized in Table 1. 
Table 1: Patients' demographics, initial and last measured limb length discrepancy and an overview of conservative and operative treatment

\begin{tabular}{|c|c|c|c|c|c|c|c|c|}
\hline \hline $\begin{array}{c}\text { Patient } \\
\text { numbe } \\
\mathrm{r}\end{array}$ & Sex & Side & $\begin{array}{c}\text { Initial } \\
\text { LLD } \\
(\mathrm{mm})\end{array}$ & $\begin{array}{c}\text { No of } \\
\text { casts }\end{array}$ & AFO & $\begin{array}{c}\text { Age at last } \\
\text { follow up }\end{array}$ & $\begin{array}{c}\text { Last } \\
\text { measured } \\
\text { LLD (mm) }\end{array}$ & Treatment \\
\hline 1 & $\mathrm{~F}$ & $\mathrm{R}$ & 19 & 9 & Yes & 12 & 39 & Shoe lift $^{* *}$ \\
\hline 2 & $\mathrm{~F}$ & $\mathrm{R}$ & 12 & 7 & Yes & 11 & $35^{* * *}$ & Lengthening \\
\hline 3 & $\mathrm{~F}$ & $\mathrm{R}$ & 8 & 4 & Yes & 5 & 15 & Shoe insert \\
\hline 4 & $\mathrm{~F}$ & $\mathrm{R}$ & 11 & 8 & Yes & 6 & $27^{* * *}$ & Lengthening \\
\hline 5 & $\mathrm{~F}$ & $\mathrm{R}$ & 9 & 5 & $\mathrm{No}$ & 5 & 12 & Shoe insert \\
\hline 6 & $\mathrm{M}$ & $\mathrm{L}$ & 7 & 4 & $\mathrm{No}$ & 2 & 12 & Shoe insert \\
\hline \hline
\end{tabular}

*LLD - limb length discrepancy

** Patient's parents refused lengthening procedure.

*** Last limb inequality measured before the lengthening procedure

\section{RESULTS}

In the study period, six children (five girls and one boy) were treated for CPMBT in our institution. In five patients, the right side was affected. None of the patients had associated anomalies. Patients with CPMBT underwent thorough clinical examination, ultrasound of the head, heart and abdomen in order to rule out other anomalies. Blood samples for routine genetic analysis were drawn in delivery units as per healthcare regulations. All patients were referred within the first three days of life. Three patients from our center were seen on the first day of life and patients from the regional centers were examined on the second or third day of life. All patients had posterior and medial angulation in the distal third of the tibia. Four patients had severe calcaneovalgus. In other two patients, feet were in extreme calcaneovalgus, lying on the antero- medial surface of the lower leg (Figure 1). First in the series of corrective casts was applied during the first visit. Casts were changed in 5-10-day intervals. Each subsequent cast was applied in a more corrected position. The average of 6.17 corrective casts were applied (range 4-9) until the correction of calcaneovalgus deformity. After a full correction of calcaneovalgus was achieved, a removable splint was applied and physiotherapy began. The splint was worn during the whole day for three months. Removal of splint was allowed only for physiotherapy and exercises at home and bathing. After three months, day-time wearing of splint was discontinued. Children continued to wear splint only at night until the end of the first year. In four patients, AFO was prescribed because of persistent angulation after the walking age. They had protective walk with AFO until the end of the second year of life, when bowing decreased sufficiently.

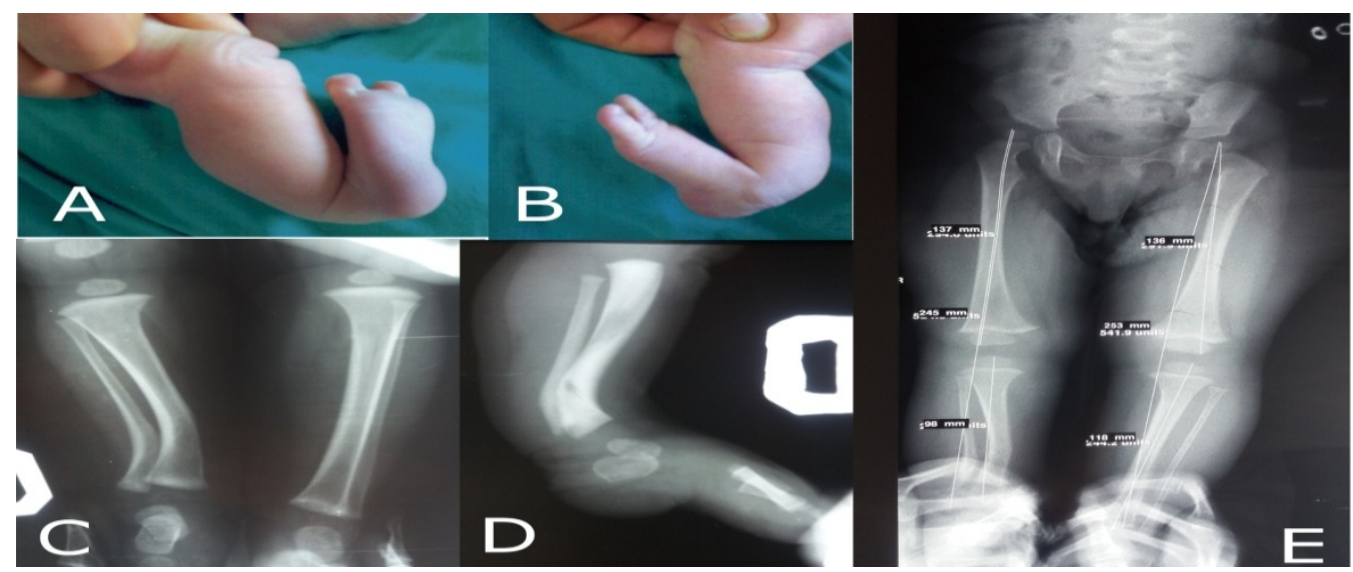

Figure 1.One-day-old girl with CPMBT at presentation (Case 1). Extreme calcaneovalgus position of the right foot. Posterior and medial angulation of the right tibia can be seen. Clinical appearance (A and B). Radiographs in AP (C) and lateral view (D) of the same patient. Limb length discrepancy measured on radiographs of full length of both limbs at the age of one was $20 \mathrm{~mm}$. Residual medial bowing of tibia is noticeable 
Mean abbreviation at presentation was $11 \mathrm{~mm}$ (range 7$19 \mathrm{~mm}$ ). In all patients, an increase in LLD was observed with growth (Figure 2). Three patients had LLD $<20$ $\mathrm{mm}$. Two of them did not limp. the third child had LLD of $15 \mathrm{~mm}$, with mild limping. She was prescribed shoe insert which fully compensated for her LLD. The parents of one girl, 12 years old, refused any kind of equalization surgery despite her LLD of $39 \mathrm{~mm}$ on the last follow-up visit. She was wearing a shoe lift which compensated for her limb length discrepancy, secondary scoliosis and limping. Two girls with LLD of $35 \mathrm{~mm}$ and $27 \mathrm{~mm}$ underwent limb lengthening by Ilizarov method when they were six years old. Lengthening of $1 \mathrm{~mm}$ per day was performed until overcorrection of $5 \mathrm{~mm}$ was achieved (40 $\mathrm{mm}$ and $32 \mathrm{~mm}$, respectively) to compensate for possible further shortening of tibia in the remaining period of growth. In one patient, lengthening was performed over titanium elastic intramedullary nails. A frame was removed after 17 weeks. In the other girl we applied a locking plate to bridge distraction callous and allow the removal of Mlizarov frame after a total of 10 weeks (6 weeks after the end of distraction). Both patients had mild complications in the form of skin irritation and superficial skin infection around the pins during distraction, which was resolved by the administration of oral antibiotics. No pin removal, hardware change or alteration of treatment plan was necessary. In one girl (case 2), transient peroneal neuropraxia was observed in the final stages of distraction. Nevertheless, the signs of neuropraxia completely resolved over time. The mean follow-up period was 6.83 years (2-12 years). Patients with lengthening procedures were followed up for five years and a half. None of the six patients has reached skeletal maturity yet and will be observed periodically for possible LLD until cessation of growth.

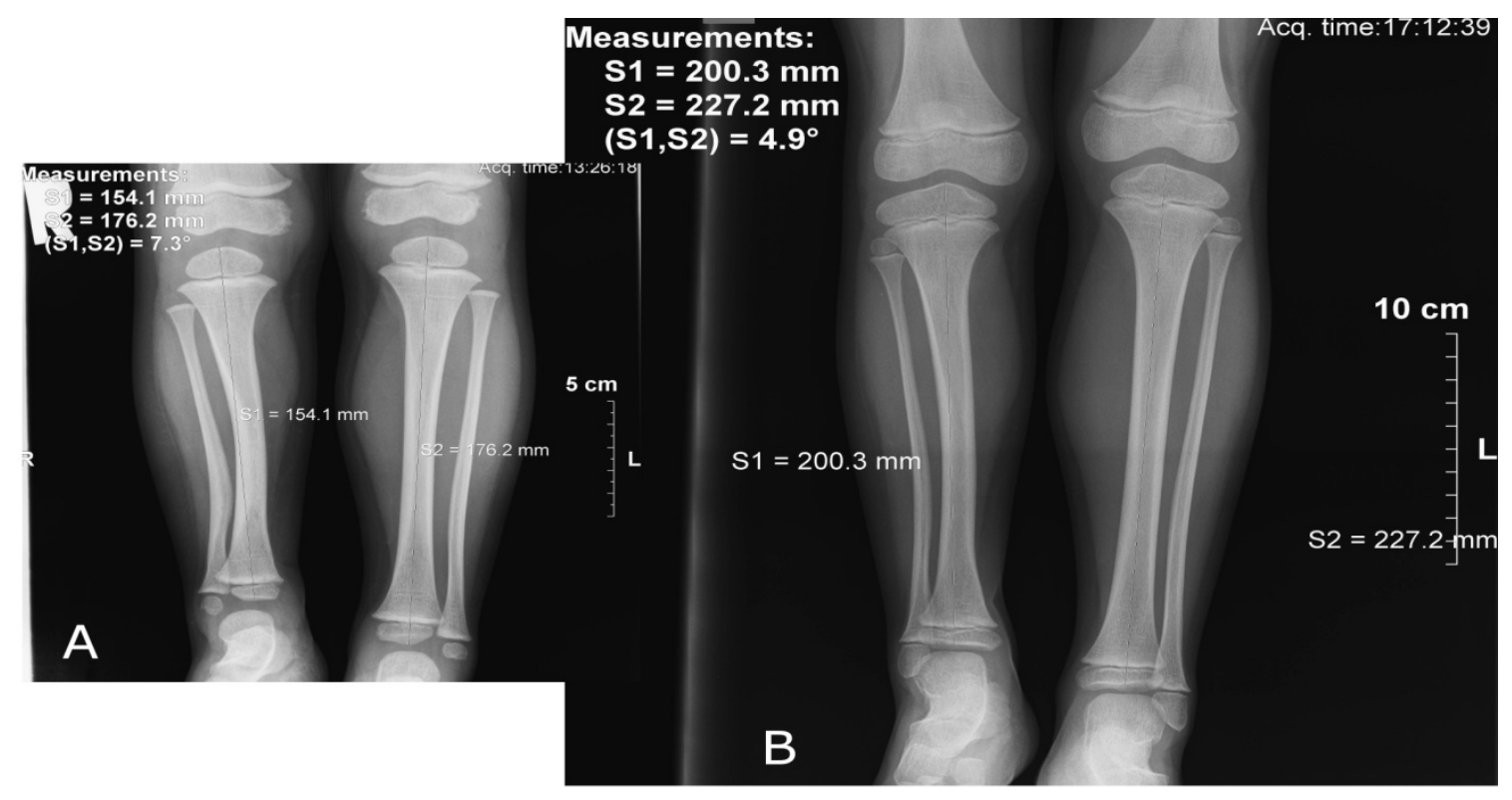

Figure 2. Progression of LLD with growth (Case 4). On AP x-ray at the age of two years, the right tibia was shorter by $22 \mathrm{~mm}$ (A). Progression of shortening to $27 \mathrm{~mm}$ at an age of 5 years (B)

\section{DISCUSSION}

Congenital posteromedial bowing of tibia is a rare anomaly of the lower limbs, usually affecting only one limb. Only one case of bilateral involvement has been described so far (6). Although no gender or side predominance has been described in the published research $(1,2,7)$, there is a strong female predominance (5:1) and the right side affection (5:1) in our patients. We could not find an explanation for this occurrence in the available literature. All patients presented early after birth and conservative treatment was instituted immediately. Bowing was located more frequently in the distal than in the middle third, and posterior angulation was of a greater magnitude than medial bowing. Those findings are similar with other reports $(1,2,5)$. Bowing of tibia is almost uniformly accompanied with calcaneovalgus of various degree $(2,7,11)$. Severe calcaneovalgus foot deformity was present in all six of our patients. After several the above knee casts, followed by splinting, physical therapy and home exercises program, calcaneovalgus deformity was fully corrected. By the end of the first year of life, normal range of ankle movements was reached, which is in our opinion 
primarily a result of vigorous stretching exercises regimen. Nevertheless, with further growth, all children but one developed decrease in ankle range of motion to some extent as expected and described previously (5). Only one patient (case 1) with LLD of $3.9 \mathrm{~cm}$, whose parents refused equalization, has a significantly reduced range of ankle motion of 950 of dorsiflexion (extension) and 250 of plantar flexion. Angulation in both planes slowly corrects over time. Two different mechanisms are probably responsible for the correction of tibial angulation (6). Physeal realignment is faster, while diaphyseal remodeling is a slower remodeling process. Full correction of medial bow may be expected, and was observed in five children. Only the youngest patient, 2.5 years old, still has 50 of medial angulation. Conversely, posterior angulation may not be fully corrected spontaneously and persist in half of our patients, but in none of them requires surgical correction. In patients with residual angulation of tibia after the walking age, AFO orthosis may help in the prevention of pathological fractures and is recommended by some authors, despite a lack of scientific support (9). Four of our patients wore AFO until angulation spontaneously diminished. If persisting angulation is of such magnitude that affects the function of ankle and walk, early correction osteotomy is recommended by Pappas (5). Equalization by lengthening procedure may be performed simultaneously. Recently, Napiontek (10) has recommended multilevel osteotomy for the correction of bowing and LLD in patients with CPMBT. In children with LLD of $1.5-2 \mathrm{~cm}$, a simple shoe insert may be effective to prevent limping. Two of our patients currently have shoe inserts prescribed. If LLD is of greater magnitude, especially $>2.5 \mathrm{~cm}$, equalization procedure should be considered. Hofmann (7) stressed that LLD as a potential serious complication of CPMBT is not sometimes clearly presented to parents and that they are erroneously assured in spontaneous correction of deformity. We agree with his attitude that all patients with CPMBT should be regularly followed up until skeletal maturity. Contralateral epiphysiodesis is a simpler option for the correction of leg shortening in CPMBT (2), but it has certain drawbacks; it will reduce the overall height of patients and is a far less controllable process than lengthening. Pappas (5) published the largest series of 33 patients treated for CPMBT; thirty of them were treated with contralateral epiphysiodesis and only one child had the lengthening of tibia performed. Shah et al. (6) reported about two patients treated with lengthening. Johari et al. (12) performed six lengthening procedures for an average preoperative LLD of $3.93 \mathrm{~cm}$. Finally, Kaufman (2) has recently published the results of treatment of 11 patients whose mean LLD was $3.7 \mathrm{~cm}$. The lengthening procedure allows a full control of the elongation process and it also offers a possibility of a simultaneous correction of residual angulation. Furthermore, complex tri-plane corrections are possible only with circular frames (2). Angulation may be corrected acutely, if a mono-lateral or gradual fixator is applied with utilization of a circular type of fixator. In three of our patients, equalization surgery was indicated, for mean LLD of $33.66 \mathrm{~cm}$. After thorough explanation and discussion, the parents of one girl (case 1) with LLD of $3.9 \mathrm{~cm}$ did not accept any surgery. The child was 12 years old at last follow-up visit. She is wearing a shoe lift of $4 \mathrm{~cm}$. Other two patients were operated on. We used light titanium circular fixator manufactured by Syntes@ . Surgery was performed in their sixth year of life to enable them to start their education without the stigma of LLD. Because both girls had substantial period of growth remaining, we performed overcorrection of 5 $\mathrm{mm}$. The main disadvantage of lengthening with external fixators is a long period of fixator wearing. This is not only uncomfortable for the patients, especially of pediatric age, but represents a constant risk of pin-tract infections. Pin tract infections occurred during the course of fixator wearing in both of the treated girls, but were efficiently controlled with oral antibiotics. To reduce the wearing time of fixator, a new combined techniques of elongation over TEN (13) or insertion of locking compression plate (LCP) after competition of elongation $(14,15)$ were developed. In the first patient (Case 2), lengthening was performed over 2 titanium elastic nails (Figure 3). Insertion of TEN not only promotes the formation of distraction callous but provides better linear alignment during distraction process. In the second patient, six weeks after complition of lengthening, LCP was inserted and Ilizarov frame was subsequently removed during the same operation (Figure 4). Residual LLD after tibial lengthening in CPMBT has been observed by many authors $(2,5,6,12)$. The first of our patients on the last follow-up visit, five years after lengthening, had no LLD but $0.5 \mathrm{~cm}$ of overcorrection have been lost. She was 11 years old with several years of growth remaining. The second girl was 7 years old at the last follow up examination and still had $3 \mathrm{~mm}$ of overcorrection. As none of our patients has finished their growth yet, it is necessary to follow them up periodically because their LLD may progress to a degree that will require some kind of equalization procedure. 


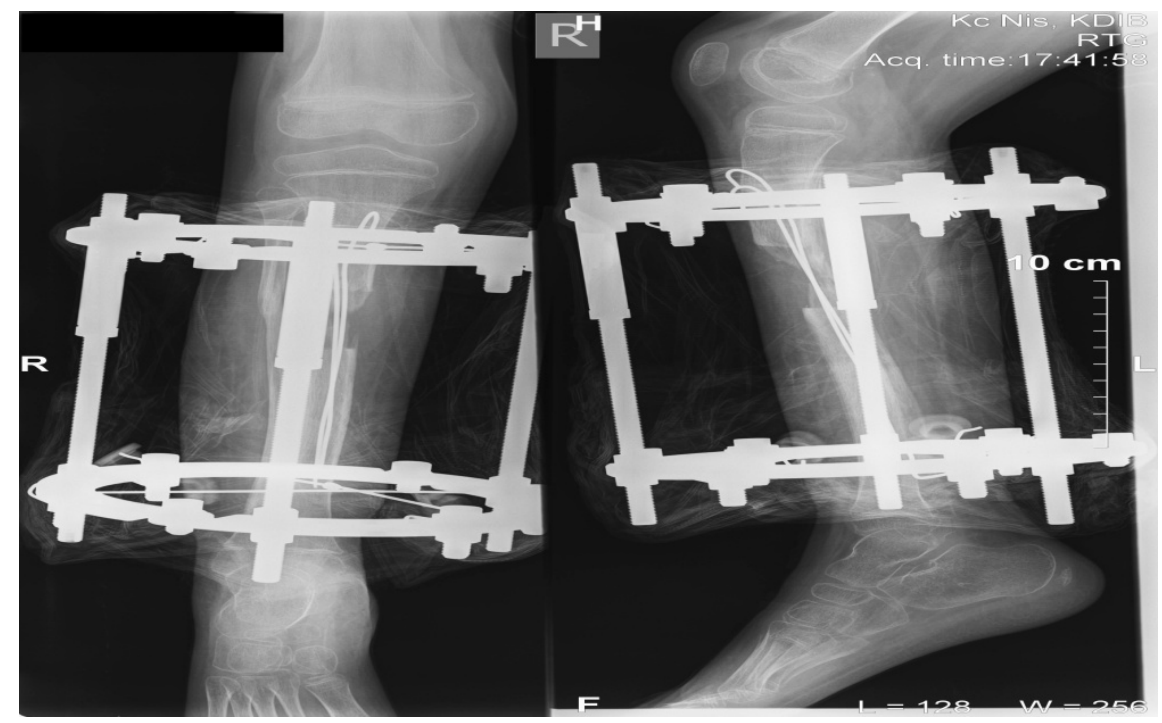

Figure 3. Combined lengthening with Ilizarov titanium frame over intramedullary titanium elastic nails (Case 2)

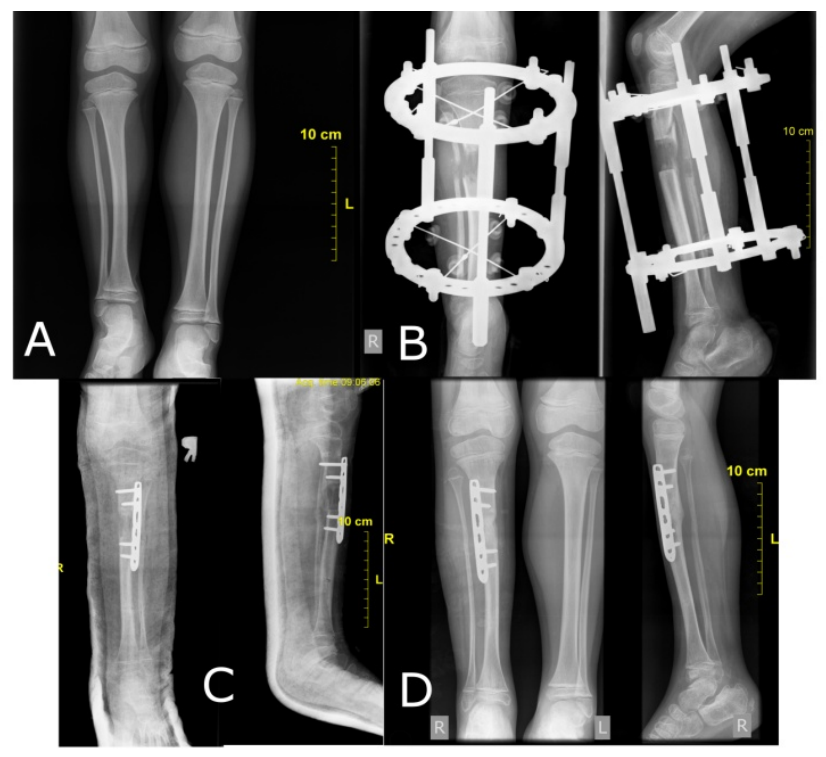

Figure 4. Combined locking plate fixation after lengthening with Ilizarov titanium frame (Case 4). LLD before lengthening was $27 \mathrm{~mm}$ (A). Near end of lengthening procedure with circular frame (B). After insertion of LCP, the circular frame was removed (C). Fully formed distraction callous, four months after the completion of distraction (D)

\section{CONCLUSION}

Congenital posteromedial bowing of the tibia (CPMBT) is a rare congenital anomaly of the lower limbs. Primary manifestation of CPMBT - angulation of tibia and fibula as well as calcaneovalgus deformity usually correct spontaneously or with conservative measures. However, limb length inequality, as a consequence of $\mathrm{CPMBT}$, progresses with growth and may require surgical correction in some children. Therefore, all children with CPMBT should be followed up until skeletal maturity. For children with shortening of more than $2-2.5 \mathrm{~cm}$, the best treatment option is Ilizarov lengthening procedure, combined with TEN or $\mathrm{LCP}$ to reduce the time spent using external fixator. Our series of patients is relatively small; however, the treatment results are good and comparable with other published studies. 


\section{References}

1. Zollinger PE, Wessels MW, Wladimiroff JW, Diepstraten AFM. Prenatal ultrasonographic diagnosis of posteromedial bowing of the leg: two case reports. Ultrasound Obstet Gynecol. 2000;15:150-3.

https://doi.org/10.1046/j.1469-0705.2000.00048.x

2. Kaufman SD, Fagg JA, Jones $S$ et al. Limb lengthening in congenital posteromedial bow of the tibia.Strateg Trauma Limb Reconstr. 2012;7:147-53. https://doi.org/10.1007/s11751-012-0145-4

3. De Maio F, Corsi A, Roggini $\mathrm{M}$ et al. Congenital Unilateral Posteromedial Bowing of the Tibia and Fibula: Insights Regarding Pathogenesis from Prenatal Pathology: A Case Report. J Bone Joint Surg Am. 2005;87:1601-5.

4. Yadav SS, Thomas S. Congenital posteromedial bowing of the tibia. Acta Orthop Scand. 1980;51:3113.

https://doi.org/10.3109/17453678008990804

5. Pappas AM. Congenital posteromedial bowing of the tibia and fibula. J PediatrOrthop. 1984;4:525-31. https://doi.org/10.1097/01241398-198404050-00001

6. Shah HH, Doddabasappa SN, Joseph B. Congenital posteromedial bowing of the tibia: a retrospective analysis of growth abnormalities in the leg. J PediatrOrthop B. 2009;18:120-8. https://doi.org/10.1097/BPB.0b013e328329dc86

7. Hofmann A, Wenger DR. Posteromedial bowing of the tibia. Progression of discrepancy in leg lengths. J Bone Joint Surg Am. 1981; 63:384-8. https://doi.org/10.2106/00004623-198163030-00010

8. Bray CB, Follows JW. Congenital posterior angulation of tibia and fibula. South Med J. 1975; $68: 292-6$.

\section{https://doi.org/10.1097/00007611-197503000-00008}

9. Mohanty RK, Training R. Effect of bracing on rate of resolution in postero- medial bowing of tibia॰: A short term case study. Indian J Med Healthcare. 2012; 1:104-7.

10. Napiontek M, Shadi M. Congenital posteromedial bowing of the tibia and fibula. J Pediatr Orthop B. 2014; 23:130-4. https://doi.org/10.1097/BPB.0000000000000024

11. French SM, Crampton SA, Brandreth DL. Posteromedial bowing of the tibia and fibula: a literature review and case presentation. J Foot Surg. 1987;26:60-5.

12. Johari AN, Dhawale AA, Salaskar A, Aroojis AJ. Congenital postero-medial bowing of the tibia and fibula: is early surgery worthwhile? J Pediatr Orthop B. 2010;19:479-86. https://doi.org/10.1097/BPB.0b013e32833ccac2

13. Bukva B, Brdar R, Nikolic D, et al. Combined external fixation and intramedullary alignment in correction of limb length discrepancies. Acta Orthop Belg. 2013; 79:411-6.

14. Grünwald L, Döbele S, Höntzsch D, et al. Callus massage after distraction osteogenesis using the concept of lengthening then dynamic plating. Strategies Trauma Limb Reconstr. 2015;10:129-35. https://doi.org/10.1007/s11751-015-0233-3

15. Harbacheuski R, Fragomen AT, Rozbruch SR. Does lengthening and then plating (LAP) shorten duration of external fixation? Clin Orthop Relat Res. 2012; 470:1771-81. https://doi.org/10.1007/s11999-011-2178-2 


\title{
Kongenitalna posteromedijalna angulacija tibije: iskustva jednog centra
}

\author{
Dragoljub Živanović1,2, Anđelka Slavković1,2, Zoran Marjanović1,2 , Ivona Đorđevićc,2, \\ Nikola Bojović2 ${ }^{2}$ Milan Petrović ${ }^{1}$ \\ ${ }^{1}$ Univerzitet u Nišu, Medicinski fakultet, Niš, Srbija \\ ${ }^{2}$ Klinika za dečiju hirurgiju i ortopediju, Klinički centar Niš, Niš, Srbija
}

\section{SAŽETAK}

Kongenitalna posteromedijalna angulacija tibije (CPMBT) je retka kongenitalna anomalija donjih ekstremiteta. Cilj rada bio je da se ispita naše iskustvo u lečenju ove anomalije. Sprovedena je retrospekivna analiza svih bolesnika lečenih zbog CPMBT u peirodu od januara 2000. godine do juna 2016.

U posmatranom periodu lečeno je šest bolesnika (pet devojčica i jedan dečak), sa predominacijom zahvaćenosti desne tibije (5:1). Lečenje je započeto serijom korektivnih gipseva (4-9), kod svih bolesnika, a nakon toga, korektivnim longetama za skidanje i fizikalnom terapijom. Četvoro dece sa rezidualnom angulacijom tibije nakon prohodavanja nosilo je potkolenu ortozu (AFO), zbog prevencije patološkog preloma. I posteriorna i medijalna angulacija korigovale su se tokom vremena. Prosečno početno skraćenje tibije bilo je $11 \mathrm{~mm}$, dok je na poslednjoj kontroli iznosilo 23,33 mm. Tri bolesnika imala su skraćenje noge veće od $2 \mathrm{~cm}$. Kod dvoje, sa skraćenjem od 27 i 35, urađeno je produženje potkolenice metodom Ilizarova. Kod jedne devojčice rađeno je produženje preko intramedularnih titanijumskih klinova, dok je kod druge, nakon završenog produženja plasirana zaključavajuća kompresivna ploča (LCP) da bi se skratilo vreme nošenja fiksatora. Nije bilo ozbiljnih komplikacija lečenja. Bolesnici su praćeni $2-12$ godina (6,83 u proseku). Nijedan bolesnik još nije dostigao punu koštanu zrelost.

Primarne manifestacije CPMBT - angulacija tibije i fibule, kao i kalkaneovalgus deformitet stopala se obično koriguju spontano ili konzervativnim merama lečenja. Međutim, nejednakost dužine potkolenica, kao posledica ove anomalije, povećava se sa rastom i kod neke dece može zahtevati hiruršku korekciju. Zbog toga, sve bolesnike sa CPMBT treba redovno pratiti do kraja rasta.

Ključnereči: posteromedijalna angulacija, kongenitalna anomalija, produženje ekstremiteta, Ilizarov, korekcija deformiteta 